\title{
Estimated Glomerular Filtration Rate and Associated Clinical and Biochemical Characteristics in Type 2 Diabetes Patients
}

\author{
Abha Pandit ${ }^{1, *}$, Abhay Kumar Pandey ${ }^{2}$ \\ ${ }^{1}$ Department of Medicine, Index Medical College Indore, India \\ ${ }^{2}$ Department of Physiology, Government Medical College Banda, India
}

Copyright $\mathrm{C} 2016$ by authors, all rights reserved. Authors agree that this article remains permanently open access under the terms of the Creative Commons Attribution License 4.0 International License

\begin{abstract}
Background: Improved check on cardiovascular mortality due to diabetes has fast increased life span and prevalence of nephropathy in diabetics world over. Its variegated insidious sequel requiring useful markers for timely detection and address. Professional dictat is for periodic monitoring of estimated glomerular filtration rate (eGFR) in the diabetes patients. An indication of nephropathy from overall routine clinical and laboratory findings is worthwhile too. Objective: Study of clinico-demographic and biochemical indices associated with diabetic nephropathy defined by cutoff decline in eGFR, was undertaken to generate local evidence base for practice guidance. Method: 136 patients of type 2 diabetes mellitus under treatment at medicine outdoor for at least past one year were classified by eGFR cutoff of $60 \mathrm{ml} / \mathrm{min} / 1.73 \mathrm{~m}^{2}$ in to renal impaired (chronic kidney disease CKD group) and unimpaired groups. In a cross sectional study their clinico-demographic characteristics and biochemical investigation profiles were analysed and compared to elucidate local clinical evidence on relevant markers of CKD in type 2 diabetes. Result and Conclusion: Central obesity, long standing disease, inadequate glycaemic control, macroproteinuria, lower HDL-cholesterol and lower plasma antioxidant capacity profiles prominently associated diabetic patients with CKD. Hypertension was not prominently associated. Weight reduction, antioxidant nutrient supplements, better glycaemic control and improvement of HDL-cholesterol profiles were apparently demanding greater attention and care toward abetting/retarding occurrence of nephropathy in type 2 diabetes patients.
\end{abstract}

Keywords Diabetic Nephropathy, Chronic Kidney Disease, Estimated GFR, Type 2 Diabetes, Diabetic Complications

\section{Introduction}

Kidney disease in type 2 diabetes patients is very heterogeneous, modulated both by microangiopathy (subsequent glomerulopathy) and atherosclerosis, as bases for renal dysfunction without albuminuria [1]. Proinflammatory cytokines of diabetes associated chronic inflammatory state cause haemodynamic alterations promoting proteinuria and kidney disease [2,3]. Albuminuria is most commonly employed indication to asses progression of kidney damage among people including the diabetics. However, type 2 diabetic patients may suffer progressive renal dysfunction without significant albuminuria [4].Incipient diabetic nephropathy is precursor of overt disease and is characterized by early microalbuminuria in disease course and a supranormal GFR. Subsequently the GFR declines before clinical proteinuria supervenes. Blood pressure starts to rise in the incipient stage. Early renal changes also predict a high risk for subsequent proliferative nephropathy. Insulin and antihypertensive therapy have shown protective potential in reversing the increases in albuminuria in longitudinal studies [5]. Glomerular hyperfiltration in early diabetes is risk factor for progressive nephropathy and may be influenced by age, disease duration and glycaemic control[6].Diabetic hyperfiltration is often attributed to glomerular haemodynamics and tubular factors altered by hyperglycaemia, and are not seen commonly in type 2 diabetes but in type 1 diabetes [7].In addition to factors in the preglomerular circulation, efferent vasoconstriction related to renin-angiotensin system (RAS) activation appewars to play important role in pathogenesis of glomerular hyperfiltration [8].

The alternative tubular hypothesis proposes that hyperfiltration is initiated by increased sodium reabsorption in the proximal renal tubules mediated by sodium glucose co-transporter 2 (SGLT2) [9].This results in supranormal rise in glomerular filtration rate [10].Glucose intolerance, even before occurrence of type 2 diabetes,induces hyperfiltration [11]. Hyperinsulinaemia/insulin resistance appear associated to development of hyperfiltration $[12,13]$. Studies indicate that increased blood pressure may be early occurrence in diabetic renal disease [14]. However, raised blood pressure may be the result of structural abnormality induced in renal glomeruli by metabolic and haemodynamic 
combined alterations in diabetes, $\mathrm{I} n$ which mesangial expansion plays important role [15].Elevated blood pressure in turn may accelerate diabetic renal impairement [16].

Diabetic nephropathy develops in $40 \%$ to $60 \%$ of type 2 diabetes patients and is characterized by progressive and persistent decline in kidney function, which leads to end stage renal disease over time [17]. Screening early signs of nephropathy provide an opportunity for early treatment, which can preserve renal function. Current recommendation is for annual screening of diabetic nephropathy (DN) with evaluation of urinary excretion of albumin and eGFR by equations that include serum creatinine [18]. Diabetic nephropathy can be secondary to long term metabolic abnormalities present in diabetics, interacting with genetic background and other environmental factors. Improved glycaemic and blood pressure control have thus shown preventive potential.CKD is current global health problem, as type 2 diabetes is its commonest cause. Also important forms of interventions are actions guided to change the patient's lifestyle, which is crucial to stop progression of CKD. Dieting, exercising, control of blood pressure and blood glucose, dyslipidaemia and obesity are all more effective measures than oral antidiabetic drugs. This study explored the clinical evidence base of current understanding in local type 2 diabetes patients with and without nephropathy defines by eGFR, for practice guidance.

\section{Patients and Method}

Study was conducted in medicine outdoor patients at Index Medical College hospital, Indore, Madhya Pradesh (India), over September 2015 to March2016 period. Protocol of the observational study was approved by superior research authority and patients were included consequent to informed free consent. Assurance was given to not reveal any personal identities without their concurrence. The cross sectional descriptive and analytical study was carried out in diagnosed type 2 diabetes mellitus patients in age range of 40 to 70 years, under outdoor management for at least 1 year. Exclusion criteria were individuals older than 70 years and with impairment of independent mobility. Patients on insulin therapy were also excluded.

History eliciting demographic information, renal related complaints and drug use was taken. Anthropometric measurements were weight in kilograms, height in meters; minimal waist circumference and maximal hip circumferences in centimeters. Blood pressure was measured using mercury sphygmomanometer in supine position every minute for 10 minutes to get values of systolic and diastolic pressures in $\mathrm{mmHg}$. Subjects were asked to provide 24 hour urine collection on two consecutive days. Collection was to be avoided in case of fever or urinary tract infection symptoms or any heavy exertion day before. Measurements of urine volume and albumin and creatinine concentration were done for each collection

Among the 136 subjects 54 were having under $60 \mathrm{ml} / \mathrm{min} / 1.73 \mathrm{~m}^{2}$ GFR (CKD group), and $82 \mathrm{did}$ not have renal impairment. There were mostly male patients (104), with only 32 female patients. Majority ( 87 subjects) were in age group of 55 to 65 years.

Body mass index was calculated using ratio of body weight and height squared $\left(\mathrm{kg} / \mathrm{m}^{2}\right)$ and classified taking 25 $\mathrm{kg} / \mathrm{m}^{2}$ as cut off for Indians. Obesity /overweight cut off BMI was more than $25 \mathrm{~kg} / \mathrm{m}^{2}$ [19]. Central fat distribution was by waist circumference cut off over $85 \mathrm{~cm}$ in males and over 80 $\mathrm{cm}$ in females. Waist/hip ratio was having cut off at 0.88 for males and 0.8 for females. Cut offs for systolic blood pressure was $140 \mathrm{mmHg}$ and for diastolic $90 \mathrm{mmHg}$.

Glomerular filtration rate was estimated (eGFR) in all subjects using abbreviated equation of the 4 variable modification of diet in renal diseases (MDRD formula). The formula is for singular Indian ethnicity[20].

eGFR $\mathrm{ml} / \mathrm{min} / 1.73 \mathrm{~m}^{2}=186 x$ serum creatinine level-1.154 $x$ age $x 0.742$ if women

Renal impairment was defined as eGFR less than $60 \mathrm{ml} / \mathrm{min} / 1.73 \mathrm{~m}^{2}$ (i.e stage II of KDOQI and beyond).

Urine albumin excretion rate was measured from 24 hour urine sample by immune-nephalometric method. Abnormal albuminuria was over $30 \mathrm{mg} /$ day urinary excretion. Proteinuria was taken as indicator of kidney damage [21].It was defined as presence of protein in urine as detected by dipstick (Teco diagnostics) reading $1+(300 \mathrm{mg} / \mathrm{L})$ or more.

Venous blood was drawn the morning after overnight fast. Serum creatinine was measured using a Jaffe rate-blanked and compensated assay. Lipid and other biochemical blood measurements were determined by standard laboratory procedures. LDL cholesterol was calculated using Friedewalds equation. Glycosylated haemoglobin (HbAlc) was measured by automated liquid chromatography analyser (Biorad Diamat).Upper limit of normal was taken as HbAlc $5.6 \%$.

Adult treatment panel III,2001[22], cut offs of abnormality for lipids were followed: total cholesterol over $200 \mathrm{mg} / \mathrm{dl}$, LDL cholesterol over $100 \mathrm{mg} / \mathrm{dl}$, triglycerides over $150 \mathrm{mg} / \mathrm{dl}$.HDL cholesterol was taken as low when under $40 \mathrm{mg} / \mathrm{dl}$ in men and under $50 \mathrm{mg} / \mathrm{dl}$ in women

Malonaldialdehyde serum level was determined as thiobarbituric acid reactive substances[23], as oxidative stress indicator. Total plasma antioxidant capacity was determined by FRAP(Ferric oxide reducing ability of plasma) method. Colourless ferric tri-pyradyl-triazine complex is reduced by plasma sample to a blue ferrous complex due to the contained antioxidants. The change in absorption is measured at 4 minute reaction time at $593 \mathrm{~nm}$ which directly indicates total reducing power of electron donating antioxidants present in plasma[24].

\section{Observations and Result}

As displayed in table-1 below, more of diabetic CKD patients were older than those with unimpaired renal function. As such there was marked predominance of males in the sample and hence $83.3 \%$ of CKD group were males, while $72 \%$ of unimpaired renal function group were males. 
Proportion of cases with longer than 10 year since disease diagnosis was $53.7 \%$ in CKD group in contrast to majority of nonCKD diabetics (70.7\%) with disease diagnosis under 10 years. Overweight/obesity had one and half time greater prevalence among CKD group of diabetics (63\%), as compared to non CKD group (39\%).More striking difference is in fat distribution patterns. $72.2 \%$ of CKD diabetics exhibited central fat distribution pattern while $70.7 \%$ among non $\mathrm{CKD}$ had peripheral fat distribution pattern.

As shown below in table-2, glycaemic control was far worse in the diabetics with CKD, with as high as $83.3 \%$ displaying $\mathrm{HbA} 1 \mathrm{c}$ higher than $7 \%$. Blood pressure profiles did not show marked contrasts, yet hypertension was slightly more prevalent in the CKD group $(66.7 \%$ as compared to $55 \%$ in nonCKD group). Normal buminuria was present in $42.7 \%$ of non CKD group but also in $7.4 \%$ of the CKD group of type 2 diabetics. A large majority in CKD group (68.5\%) and larger half $(57.3 \%)$ od nonCKD group were in microalbuminuric range, i.e. 30 to under $300 \mathrm{mg} /$ day urinary albumin excretion. $24 \%$ of exclusive diabetic CKD group exhibited frank proteinuria, more than $300 \mathrm{mg} /$ day urinary albumin excretion. Lipid profile did not reveal many striking contrasts between two groups, except that low HDL-cholesterol was observed in $39 \%$ of the CKD group as opposed to $20 \%$ of nonCKD group patients. Plasma malondialdehyde levels were higher than normal, e.g. under 2 micromoles/l in both groups of type 2 diabetics, with the CKD group exhibiting only marginally higher levels. Plasma total antioxidant capacity was almost half of normal 1000 micromoles/ 1 in both groups of type 2 diabetics. The CKD group had 30\% lower antioxidant capacity as compared to the nonCKD group of diabetics.

Table 1. Clinical and demographic profile of type 2 diabetes patients with or without significant reduction of GFR

\begin{tabular}{|c|c|c|}
\hline Parameters & Type 2 Diabetics with eGFR below $60 \mathrm{ml} / \mathrm{min} / 1.73 \mathrm{~m}^{2}$ & Type 2 diabetics with eGFR $60 \mathrm{ml} / \mathrm{min} / 1.73 \mathrm{~m}^{2}$ and above \\
\hline eGFR $\mathrm{ml} / \mathrm{min} / 1.73 \mathrm{M} 2$ & $51.3 \pm 8.6$ & $82.2 \pm 17.2$ \\
\hline $\mathrm{N}$ & 54 & 82 \\
\hline \multicolumn{3}{|c|}{ Age in years } \\
\hline Under 60(n) & $32(59.3 \%)$ & $38(46.3 \%)$ \\
\hline Above $60(\mathrm{n})$ & 22 & 44 \\
\hline \multicolumn{3}{|c|}{ Gender } \\
\hline Males (n) & $45(83.3 \%)$ & $59(72 \%)$ \\
\hline Females(n) & 9 & 23 \\
\hline \multicolumn{3}{|c|}{ Duration since diagnosis } \\
\hline More than 10 years $(\mathrm{n})$ & $29(53.7 \%) *$ & $24(29.3 \%)$ \\
\hline Under 10 years $(\mathrm{n})$ & 25 & 58 \\
\hline \multicolumn{3}{|l|}{ BMI kg/m² } \\
\hline Under $25(\mathrm{n})$ & 20 & 50 \\
\hline Over $25(\mathrm{n})$ & $34(63 \%) *$ & $32(39 \%)$ \\
\hline \multicolumn{3}{|c|}{ W/H Ratio } \\
\hline High (n) & $39(72.2 \%)^{*}$ & $24(29.3 \%)$ \\
\hline Normal (n) & 15 & 58 \\
\hline
\end{tabular}

* Statistically significant difference (Chi square test)

Table 2. Biochemical investigation profiles of type 2 diabetes patients with or without significant reduction of GFR

\begin{tabular}{|c|c|c|}
\hline Parameters & Type 2 Diabetics with eGFR below $60 \mathrm{ml} / \mathrm{min} / 1.73 \mathrm{~m}^{2}$ & Type 2 diabetics with eGFR $60 \mathrm{ml} / \mathrm{min} / 1.73 \mathrm{~m}^{2}$ and above \\
\hline \multicolumn{3}{|c|}{$\mathrm{HbA1c} \%$} \\
\hline Under 7(n) & 9 & 59 \\
\hline Above 7 (n) & $45^{*}$ & 13 \\
\hline \multicolumn{3}{|c|}{ BP (Systolic) } \\
\hline under $140 \mathrm{mmHg}(\mathrm{n})$ & 18 & 37 \\
\hline above $140 \mathrm{mmHg}(\mathrm{n})$ & 36 & 45 \\
\hline \multicolumn{3}{|c|}{ BP (Diastolic) } \\
\hline under $90 \mathrm{mmHg}(\mathrm{n})$ & 18 & 37 \\
\hline above $90 \mathrm{mmHg}(\mathrm{n})$ & 36 & 45 \\
\hline \multicolumn{3}{|c|}{ Albuminuria mg/day } \\
\hline Under $30(n)$ & $4(7.4 \%)^{*}$ & $35(42.7 \%)$ \\
\hline $30-300(n)$ & $37(68.5 \%)$ & $479(57.3 \%)$ \\
\hline Above $300(\mathrm{n})$ & $13(24 \%)$ & 0 \\
\hline \multicolumn{3}{|c|}{ Lipid profile } \\
\hline \multicolumn{3}{|c|}{ Triglycerides } \\
\hline under $150 \mathrm{mg} / \mathrm{dl}(\mathrm{n})$ & 8 & 22 \\
\hline over $150 \mathrm{mg} / \mathrm{dl}(\mathrm{n})$ & $46(85 \%)$ & $60(73.2 \%)$ \\
\hline \multicolumn{3}{|c|}{ LDL-C } \\
\hline under $100 \mathrm{mg} / \mathrm{dl}(\mathrm{n})$ & 41 & 57 \\
\hline over $100 \mathrm{mg} / \mathrm{dl}(\mathrm{n})$ & $13(24 \%)$ & $25(30.5 \%)$ \\
\hline \multicolumn{3}{|c|}{ HDL-C } \\
\hline over 40 (f.50) $\mathrm{mg} / \mathrm{dl}(\mathrm{n})$ & 33 & 65 \\
\hline under 40 (f.50) mg/dl (n) & $21(39 \%)^{*}$ & $17(20 \%)$ \\
\hline $\begin{array}{c}\text { Malonaldehyde } \\
\text { micromoles/L }(\text { Mean } \pm \mathrm{SD})\end{array}$ & $4.12 \pm 0.88$ (higher $9 \%$ ) & $3.78 \pm 0.85$ \\
\hline $\begin{array}{l}\text { Plasma ferric reducing } \\
\text { ability micromoles } / \mathrm{L} \\
(\text { Mean } \pm \mathrm{SD})\end{array}$ & $416 \pm 91.2(\text { lower } 30 \%)^{*}$ & $598 \pm 112.5$ \\
\hline
\end{tabular}




\section{Discussion}

Type 2 diabetes mellitus is leading cause for chronic kidney disease. Advanced interventions managing coronary artery disease prolongs life, especially in diabetics, increasing scope for occurrence of renal failure. Multiple factors are considered to contribute to initiation and prolongation of diabetic nephropathy, viz. proteinuria, hyperglycaemia, hypertension, genetic susceptibility, ethnicity, high protein intake and familial predisposition to renal disease [25].Early identification and treatment of risk factors for kidney damage in diabetic subjects may represent best strategy to prevent ominous cardiorenal consequences [26].The cluster of metabolic abnormalities constituting metabolic syndrome have been shown to associate compromise of renal function [27]. Each of defined elements of metabolic syndrome increases prevalence of microalbuminuriua and chronic kidney disease and more the number of components present higher is the later prevalence .Many mechanisms of renal damage, consequent to obesity initiated metabolic syndrome are proposed. Independent and combined adverse impacts of adaptations to increased body mass/excretory load; impact of adaptations to obesity induced sodium retention [28]; direct or indirect effects of hyperinsulinaemia/insulin resistance and renal lipotoxicity $[29,30]$.

Currently, the abbreviated MDRD formula with four variables has been recommended, because its performance is as good. GFR below $60 \mathrm{ml} / \mathrm{min} / 1.73 \mathrm{~m}^{2}$ represents a decrease of approximately $50 \%$ in normal renal function, below which prevalence of complications of CKD increases [31]. GFR however is influenced by individual, ethnic and disease specific conditions $[32,33]$. Glomerular filtration rate is on average, underestimated by both the CockCroft Gault and MDRD equations. These therefore overestimate prevalence of impaired renal function, when applied in epidemiological studies. On the other hand, patients with incipient diabetic nephropathy and hyperfiltration (potentially having an increased risk of progression of diabetic nephropathy), will therefore be missed by underestimation of GFR by the formulae. The formulae have limitations in predicting renal function in healthy subjects and in patients at early diabetic nephropathy. The formulae perform best in subjects with impaired renal function. Microalbuminurics are hyperfiltrating, eGFR in them is underestimated.

Validity of eGFR is affected by many other factors besides glomerular filtration, e.g. serum creatinine level; tubular secretion of creatinine; impact of skeletal muscle mass, meat intake; inhibition of tubular creatinine secretion by drugs as cimetidine. With declining renal function, the tubular secretion and external clearance of creatinine increase leading to underestimation by eGFR [34].The eGFR applications provide means for early easy determination of renal function so valuable for interventions to prevent and reduce renal failure.

Old age associates decline in kidney function and clear contribution to decreased glomerular filtration as studied also in type 2 diabetes patient cohort [35].Another large study over 10 years in 3047 aging subjects female gender was seen associated with slower decline in GFR and better renal survival [36]. Duration of disease is very important factor in the development of diabetic nephropathy and relates to severity of glomerulopathy [37]. Overt nephropathy was found to appear after 5 to 10 years of diagnosis of type 2 diabetes [38]. In a study of 35 year plus aged type 2 diabetes patients, occurrence of nephropathy at next 10 years was in $40 \%$ cases and in next 15 years it was in $61 \%$ of cases [39]. Adler et al [40] described natural history of renal disease in newly diagnosed diabetics. The patients progressed from no nephropathy to microalbuminuria at rate of $2 \%$ per year; then to macroalbuminuria at $2.8 \%$ per year and finally to elevated plasma creatinine and need for renal replacement therapy at $2.3 \%$ per year rate. Very few instances of jumping over stage were observed in 10 yearlong study. In a Saudi cohort $3.3 \mathrm{ml} / \mathrm{min} / 1.73 \mathrm{~m}^{2}$ decline in GFR was deduced per year in diabetic kidney disease patients [41].

Central obesity estimated by waist to hip ratio is found to correlate inversely with kidney function [42].Obesity negatively influences the kidney increasing risk of injury and end stage disease [43]. Obesity is associated both with renal hyperfiltration, hyper-perfusion and microalbuminuria [44].Central body fat distribution is related to hyper insulinaemia, hypertension, hyperlipidaemia and atherosclerosis [45,46]. Seaglione et al [47], showed that subjects with central obesity have reduced renal plasma and blood flow and increased filtration fraction and albuminuria, but not so in case of peripheral fat distribution. Central fat distribution is related to insulin resistance. Greater insulin and glucagon levels prevail in such cases [48], affecting renal haemodynamics, GFR and albuminuria [49, 50]. Hyperfiltration is frequent early finding in patients with diabetes and predictor for development of subsequent microalbuminuria and nephropathy [51].Insulin resistance is predictor CKD even before hyperglycaemia, hence each components of metabolic syndrome promote nephropathy [52].Central obesity, in addition to alterations of haemodynamics propagates inflammatory and metabolic effects to contribute to nephropathy [53].

Glycated haemoglobin increases in diabetes in direct proportion to fasting blood glucose levels [54].It also serves as indirect marker for oxidative stress. Poor glycaemic control $(\mathrm{HbA} 1 \mathrm{c})$ is significant risk factor early in the first decade of diabetes for development of nephropathy, but not later [55].Mean $\mathrm{HbAlc}$, though is seen to remain high through course of incipient nephropathy. Chronic hyperglycaemia is strongest predictor of renal function decline in diabetics with preserved renal function when over $60 \mathrm{ml} / \mathrm{min}$ [56].A direct significant correlation of body mass indices (BMI) and fasting blood sugar profiles is reported in study on 100 men of 20 year to 40 year age [57].

Incidence of nephropathy increased significantly in parallel to rise in blood pressure in a study on 600 type- 2 diabetic patients [58]. Elevated blood pressure is early accompaniment of incipient diabetic nephropathy with 
values 10 to $15 \%$ higher than normal $[59,60]$.Systolic blood pressure rises only upon prominent structural changes in glomeruli. Even slight elevation in blood pressure accelerates course of diabetic nephropathy. Albumin excretion increases in proportion to number of fibrotic glomeruli [15].24\% of CKD patients did have proteinuria and also had hypertension (not separately shown), but in rest microalbuminuric majority hypertension does not appear to be casting significant impact.

Albuminuria is found to be strongest predictor of further decline at baseline GFR of $50 \mathrm{ml} / \mathrm{min}$ [61]. Microalbuminuria is persistent albumin excretion at levels not detected by dipsticks, i.e. between 20 to $200 \mathrm{micro} \mathrm{gm} / \mathrm{min}$. Microalbuminuria corresponds to around 30 to $300 \mathrm{mg}$ daily albumin excretion [62]. This is stage III or incipient diabetic nephropathy. When over $300 \mathrm{mg} /$ day proteinuria starts, its stage IV or overt diabetic nephropathy. Early in stage III, GFR is elevated (hyperfiltration), without increased renal perfusion. As microalbuminuria progresses, GFR returns to normal range [63]. Finally, patients entering frank proteinuric stage (over $300 \mathrm{mg} /$ day albumin excretion) exhibit gradual decrease in GFR and renal blood flow.

Alteration in serum lipids and lipoproteins are associated with microalbuminuria and may be linked to induction of glomerulopathy [64].In an Indian study on 600 newly diagnosed type 2 diabetes patients, $53.66 \%$ patients with BMI above 30 went on to develop nephropathy. Similarly, increasing dyslipidaemia increased nephropathy incidence. Diagnosis of diabetes per se did not correlate occurrence of nephropathy [58]. Dyslipidaemia in diabetes and renal disease are evidently linked. A low HDL-cholesterol was seen to predict progression of renal dysfunction independently [65].High triglyceride increased while high HDL-cholesterol decreased probability of developing renal dysfunction [66]

Free radicals play crucial role in pathology of diabetes [67], and its complications [68]. Free radicals cause lipid peroxidation that involves in degradation of biomolecules, DNA, lipids, carbohydrates all [69]. High malonaldialdehyde levels were shown to impaire insulin secretion through beta cell oxidative stress [70]. In diabetic plasma, ferric reducing ability was found to be $40 \%$ lower than normal level [71].

Observations in the present study are largely consistent with contemporary understanding. The same therefore deserves religious application in day to day management of type 2 diabetes and associated kidney dysfunction. Obesity associated metabolic syndrome and its cascading consequences may be resolved by weight loss and prevented by calorie restriction [72,73]. Pharmacologic intervention with angiotensin converting enzyme inhibitors or angiotensin receptor blockers increase insulin sensitivity and ameliorate microalbuminuria, In addition to well documented cardiovascular and renal protection and antihypertensive effect [74]. Glomerular mesangial cells mimic the vascular smooth muscle cells in atherosclerotic vessel wall and factors contributing to atherosclerosis appear to be implicated in pathogenesis of chronic kidney disease [75]. Elevated lipid levels accelerate progression of renal disease and manipulations to lower circulating lipids or prevent their intracellular accumulation would render clinical improvement [76]. Statins have role in treating hypercholesterolaemia. Their plieotropic anti-inflammatory effect holds promise even of benefiting non-cholesterolaemic metabolic syndrome. Metformin prevents development of diabetes in the prediabetics but is not safe in cases with impaired renal function. Fenofibrate (a PPAR- $\alpha$ agonist) and niacin are effective means to deal with hypertriglyceridaemia. Each of these may be combined with statins [77].

\section{Conclusions}

Nephropathy in type 2 diabetes, despite being multifactorial in origin, exhibited consistency with global experience on the disease. Ordinary routine clinic-demographic and biochemical indices appeared capable to reflect need for investigation and address of nephropathy in type 2 diabetes patients. Findings emphasize the significance of basics viz. weight reduction through physical activity, proper diet and lifestyle and regular clinical checkups in prevention and reduction of diabetic renal failure, the emerging major challenge of health care.

\section{REFERENCES}

[1] Lorenzo C, Nath SD, Hanley AJ, Abboud HE, Haffner SM. Relation of low glomerular filtration rate to metabolic disorders in individuals without diabetes and with normoalbuminuria. Clin J Am Soc Nephrol. 2008; 3(3):783-9

[2] Zatz R, Meyer TW, Rennke HG, Brenner BM. Predominance of hemodynamic rather than metabolic factors in the pathogenesis of diabetic glomerulopathy. Proc Natl Acad Sci U S A. 1985; 82(17):5963-7.

[3] Ziyadeh FN. Mediators of diabetic renal disease: the case for TGF- $\beta$ as the major mediator. J Am Soc Nephrol. 2004; 15 Suppl 1:S55-7.

[4] MacIsaac RJ, Tsalamandris C, Panagiotopoulos S, Smith TJ, McNeil KJ, Jerums G. Nonalbuminuric renal insufficiency in type 2 diabetes. Diabetes Care. 2004; 27(1):195-200.

[5] Mogensen CEMicroalbuminuria as a predictor of clinical diabetic nephropathy. Kidney Int. 1987; 31(2):673-89.

[6] Jerums G, Premaratne E, Panagiotopoulos S, MacIsaac RJ. The clinical significance of hyperfiltration in diabetes. Diabetologia. 2010 53(10):2093-104.

[7] Cherney DZ, Scholey JW, Miller JAInsights into the regulation of renal hemodynamic function in diabetic mellitus. Curr Diabetes Rev. 2008; 4(4):280-90.

[8] Sochett EB, Cherney DZ, Curtis JR, Dekker MG, Scholey JW, Miller JA. Impact of renin angiotensin system modulation on 
the hyperfiltration state in type 1 diabetes. J Am Soc Nephrol. 2006; 17(6):1703-9.

[9] Aires I, Calado J. BI-10773, a sodium-glucose cotransporter 2 inhibitor for the potential oral treatment of type 2 diabetes mellitus.Curr Opin Investig Drugs. 2010 Oct; 11(10):1182-90.

[10] Vallon V, Blantz RC, Thomson S. Glomerular hyperfiltration and the salt paradox in early [corrected] type 1 diabetes mellitus: a tubulo-centric view.J Am Soc Nephrol. 2003; 14(2):530-7.

[11] Pruijm M, Wuerzner G, Maillard M, Bovet P, Renaud C, Bochud M, Burnier M. Glomerular hyperfiltration and increased proximal sodium reabsorption in subjects with type 2 diabetes or impaired fasting glucose in a population of the African region. Nephrol Dial Transplant. 2010; 25(7):2225-31.

[12] Dengel DR, Goldberg AP, Mayuga RS, Kairis GM, Weir MR. Insulin resistance, elevated glomerular filtration fraction, and renal injury. Hypertension. 1996; 28(1):127-32.

[13] Knight SF, Imig JD. Obesity, insulin resistance, and renal function. Microcirculation. 2007; 14(4-5):349-62.

[14] Parving HH, Andersen AR, Smidt UM, Oxenbøll B, Edsberg B, Christiansen JS. Diabetic nephropathy and arterial hypertension. Diabetologia. 1983; 24(1):10-2.

[15] Mauer SM, Steffes MW, Ellis EN, Sutherland DE, Brown DM, Goetz FC. Structural-functional relationships in diabetic nephropathy. J Clin Invest. 1984; 74(4):1143-55.

[16] Parving HH, Andersen AR, Smidt UM, Svendsen PA.Early aggressive antihypertensive treatment reduces rate of decline in kidney function in diabetic nephropathy. Lancet. 198328 ; 1(8335):1175-9.

[17] Gall MA, Nielsen FS, Smidt UM, Parving HH. The course of kidney function in type 2 (non-insulin-dependent) diabetic patients with diabetic nephropathy. Diabetologia. 1993; 36(10):1071-8.

[18] American Diabetes Association. Standards of medical care in Diabetes-2010 Diabetes care 2010; 33: 11-61.

[19] Snehalatha C, Viswanathan V, Ramachandran A. Cutoff values for normal anthropometric variables in asian Indian adults. Diabetes Care. 2003; 26(5):1380-4.

[20] Leavy AS Greene T Kusek JW Beck GJ A simplified equation to predict glomerular filtration rate from serum creatinine $\mathrm{J}$ am soc nephrol 2000;11:A0828.

[21] Vassalotti JA, Stevens LA, Levey AS. Testing for chronic kidney disease: a position statement from the National Kidney Foundation. Am J Kidney Dis. 2007; 50(2):169-80.

[22] Grundy SM, Cleeman JI, Merz CN, Brewer HB Jr, Clark LT, Hunninghake DB, Pasternak RC, Smith SC Jr, Stone NJ; National Heart, Lung, and Blood Institute; American College of Cardiology Foundation; American Heart Association. Implications of recent clinical trials for the National Cholesterol Education Program Adult Treatment Panel III guidelines. Circulation. 2004; 13; 110(2):227-39.

[23] Sangeetha P, Das UN, Koratkar R, Suryaprabha P. Increase in free radical generation and lipid peroxidation following chemotherapy in patients with cancer. Free Radic Biol Med. 1990;8(1):15-9.
[24] Benzie IF, Strain JJ.The ferric reducing ability of plasma (FRAP) as a measure of "antioxidant power": the FRAP assay. Anal Biochem. 1996; 239(1):70-6.

[25] Nelson RG, Knowler WC, McCance DR, Sievers ML, Pettitt DJ, Charles MA, Hanson RL, Liu QZ, Bennett PH. Determinants of end-stage renal disease in Pima Indians with type 2 (non-insulin-dependent) diabetes mellitus and proteinuria. Diabetologia. 1993; 36(10):1087-93.

[26] KDOQI. KDOQI Clinical Practice Guidelines and Clinical Practice Recommendations for Diabetes and Chronic Kidney Disease. Am J Kidney Dis. 2007; 49(2 Suppl 2):S12-154.

[27] Chen J, Muntner P, Hamm LL, Jones DW, Batuman V, Fonseca V, Whelton PK, He J.The metabolic syndrome and chronic kidney disease in U.S. adults. Ann Intern Med. 2004; 140(3):167-74.

[28] Hall JE, Henegar JR, Dwyer TM, Liu J, Da Silva AA, Kuo JJ, Tallam L. Is obesity a major cause of chronic kidney disease? Adv Ren Replace Ther. 2004; 11(1):41-54.

[29] Unger RH. Minireview: weapons of lean body mass destruction: the role of ectopic lipids in the metabolic syndrome. Endocrinology. 2003; 144(12):5159-65.

[30] Adelman RD. Obesity and renal disease. Curr Opin Nephrol Hypertens. 2002; 11(3):331-5.

[31] Bastos MG, Bregman R, Kirsztajn GM. [Chronic kidney diseases: common and harmful, but also preventable and treatable].Rev Assoc Med Bras. 2010; 56(2):248-53.

[32] Hasslacher C, Bostedt-Kiesel A, Kempe HP, Wahl P. Effect of metabolic factors and blood pressure on kidney function in proteinuric type 2 (non-insulin-dependent) diabetic patients. Diabetologia. 1993 36(10):1051-6.

[33] Ueda H, Ishimura E, Shoji T, Emoto M, Morioka T, Matsumoto N, Fukumoto S, Miki T, Inaba M, Nishizawa Y.Factors affecting progression of renal failure in patients with type 2 diabetes. Diabetes Care. 2003; 26(5):1530-4.

[34] Shemesh O, Golbetz H, Kriss JP, Myers BD. Limitations of creatinine as a filtration marker in glomerulopathic patients. Kidney Int. 1985 28(5):830-8.

[35] Premaratne E, Macisaac RJ, Tsalamandris C, Panagiotopoulos S, Smith T, Jerums G. Renal hyperfiltration in type 2 diabetes: effect of age-related decline in glomerular filtration rate. Diabetologia. 2005; 48(12):2486-93.

[36] Eriksen BO, Ingebretsen OC.The progression of chronic kidney disease: a 10-year population-based study of the effects of gender and age. Kidney Int. 2006; 69(2):375-82.

[37] Rudberg S, Osterby R, Dahlquist G, Nyberg G, Persson B. Predictors of renal morphological changes in the early stage of microalbuminuria in adolescents with IDDM. Diabetes Care. 1997; 20(3):265-71.

[38] Tung P, Levin SR. Nephropathy in non-insulin-dependent diabetes mellitus. Am J Med. 1988; 85(5A):131-6.

[39] Nelson RG, Knowler WC, Pettitt DJ, Saad MF, Charles MA, Bennett PH. Assessment of risk of overt nephropathy in diabetic patients from albumin excretion in untimed urine specimens. Arch Intern Med. 1991; 151(9):1761-5.

[40] Adler AI, Stevens RJ, Manley SE, Bilous RW, Cull CA, 
Holman RR; UKPDS GROUP. Development and progression of nephropathy in type 2 diabetes: the United Kingdom Prospective Diabetes Study (UKPDS 64).Kidney Int. $2003 ; 63(1): 225-32$.

[41] Alwakeel JS, Isnani AC, Alsuwaida A, Alharbi A, Shaffi SA, Almohaya S, Al Ghonaim M. Factors affecting the progression of diabetic nephropathy and its complications: a single-center experience inSaudi Arabia. Ann Saudi Med. $2011 ; 31(3): 236-42$.

[42] Pinto-Sietsma SJ, Navis G, Janssen WM, de Zeeuw D, Gans RO, de Jong PE; PREVEND Study Group. A central body fat distribution is related to renal function impairment, even in lean subjects. Am J Kidney Dis. 2003; 41(4):733-41.

[43] Iseki K, Ikemiya Y, Kinjo K, Inoue T, Iseki C, Takishita S. Body mass index and the risk of development of end-stage renal disease in a screened cohort. Kidney Int. 2004; 65(5):1870-6.

[44] Basdevant A, Cassuto D, Gibault T, Raison J, Guy-Grand B. Microalbuminuria and body fat distribution in obese subjects.Int J Obes Relat Metab Disord. 1994; 18(12):806-11.

[45] Haffner SM, Stern MP, Hazuda HP, Pugh J, Patterson JK. Do upper-body and centralized adiposity measure different aspects of regional body-fat distribution? Relationship to non-insulin-dependent diabetes mellitus, lipids, and lipoproteins. Diabetes. 1987; 36(1):43-51.

[46] Seidell JC, Bakx JC, De Boer E, Deurenberg P, Hautvast JG.Fat distribution of overweight persons in relation to morbidity and subjective health. Int J Obes. 1985; 9(5):363-74.

[47] Scaglione R, Ganguzza A, Corrao S, Parrinello G, Merlino G, Dichiara MA, Arnone S, D'Aubert MD, Licata G. Central obesity and hypertension: pathophysiologic role of renal haemodynamics and function. Int J Obes Relat Metab Disord. 1995; 19(6):403-9.

[48] Solerte SB, Fioravanti M, Severgnini S, Rondanelli M, Precerutti S, Vignati G, Ferrari E. Hyperinsulinemia and glucagon serum concentrations influence renal hemodynamics and urinary protein loss in normotensive patients with central obesity.Int J Obes Relat Metab Disord. 2000; 24 Suppl 2:S122-3.

[49] Ahloulay M, Déchaux M, Laborde K, Bankir L. Influence of glucagon on GFR and on urea and electrolyte excretion: direct and indirect effects. Am J Physiol. 1995; 269(2 Pt 2):F225-35.

[50] Kubo M, Kiyohara Y, Kato I, Iwamoto H, Nakayama K, Hirakata H, Fujishima M. Effect of hyperinsulinemia on renal function in a general Japanese population: the Hisayama study.Kidney Int. 1999; 55(6):2450-6.

[51] Rudberg S, Persson B, Dahlquist G. Increased glomerular filtration rate as a predictor of diabetic nephropathy--an 8-year prospective study. Kidney Int. 1992; 41(4):822-8.

[52] Chen J, Muntner P, Hamm LL, Fonseca V, Batuman V, Whelton PK, He J. Insulin resistance and risk of chronic kidney disease in nondiabetic US adults.J Am Soc Nephrol. 2003; 14(2):469-77.

[53] Bagby SPObesity-initiated metabolic syndrome and the kidney: a recipe for chronic kidney disease? J Am Soc Nephrol. 2004; 15(11):2775-91.
[54] Koenig RJ, Peterson CM, Jones RL, Saudek C, Lehrman M, Cerami A. Correlation of glucose regulation and hemoglobin AIc in diabetes mellitus. N Engl J Med. 1976; 295(8):417-20.

[55] Pirart J Diabetes mellitus and its degenerative complications: A prospective study of 4400 patients observed between 1947 to 1973 DIABETES CARE, I: 168-188.

[56] Yokoyama $\mathrm{H}^{1}$, Kanno S, Takahashi S, Yamada D, Itoh $\mathrm{H}$, Saito K, Sone H, Haneda M. Determinants of decline in glomerular filtration rate in nonproteinuric subjects with or without diabetes and hypertension. Clin J Am Soc Nephrol. 2009; 4(9):1432-40.

[57] Prema GS Anitha R Padmini O Relation between body mass index and fasting blood sugar. International journal of contemporary medical research 2016; 3: 91-94.

[58] Patel HK Jain SK Nephropathy in newly diagnosed type 2 diabetes and the impact of hypertension. International journal of contemporary medical research 2016; 3:737-739.

[59] Mogensen CE, Christensen CK. Blood pressure changes and renal function in incipient and overt diabetic nephropathy. Hypertension. 1985; 7(6 Pt 2):II64-73.

[60] Christensen CK, Mogensen CE. The course of incipient diabetic nephropathy: studies of albumin excretion and blood pressure. Diabet Med. 1985 r; 2(2):97-102.

[61] Lorenzo V, Saracho R, Zamora J, Rufino M, Torres A. Similar renal decline in diabetic and non-diabetic patients with comparable levels of albuminuria. Nephrol Dial Transplant. 2010; 25(3):835-41.

[62] Mogensen CE, Chachati A, Christensen CK, Close CF, Deckert T, Hommel E, Kastrup J, Lefebvre P, Mathiesen ER, Feldt-Rasmussen B, et al. Microalbuminuria: an early marker of renal involvement in diabetes. Uremia Invest. 1985-1986; 9(2):85-95

[63] Mogensen CE, Christensen CK. Predicting diabetic nephropathy in insulin-dependent patients. N Engl J Med. 1984; 311(2):89-93.

[64] Watts GF, Naumova R, Slavin BM, Morris RW, Houlston R, Kubal C, Shaw KM.Serum lipids and lipoproteins in insulin-dependent diabetic patients with persistent microalbuminuria. Diabet Med. 1989; 6(1):25-30.

[65] Hunsicker LG, Adler S, Caggiula A, England BK, Greene T, Kusek JW, Rogers NL, Teschan PE. Predictors of the progression of renal disease in the Modification of Diet in Renal Disease Study. Kidney Int. 1997; 51(6):1908-19.

[66] Muntner P, Coresh J, Smith JC, Eckfeldt J, Klag MJ.Plasma lipids and risk of developing renal dysfunction: the atherosclerosis risk in communities study. Kidney Int. 2000; 58(1):293-301

[67] Feillet-Coudray C, Rock E, Coudray C, Grzelkowska K, Azais-Braesco V, Dardevet D, Mazur A.Lipid peroxidation and antioxidant status in experimental diabetes. Clin Chim Acta. 1999; 284(1):31-43.

[68] Brinkmann C, Blossfeld J, Pesch M, Krone B, Wiesiollek K, Capin D, Montiel G, Hellmich M, Bloch W, Brixius K. Lipid-peroxidation and peroxiredoxin-overoxidation in the erythrocytes of non-insulin-dependent type 2 diabetic men during acute exercise. Eur J Appl Physiol. 2012 Jun; 112(6):2277-87. 
[69] Zadák Z, Hyspler R, Tichá A, Hronek M, Fikrová P, Rathouská J, Hrnciariková D, Stetina R. .Antioxidants and vitamins in clinical conditions. Physiol Res. 2009; 58 Suppl 1:S13-7.

[70] Drews G, Krippeit-Drews P, Düfer M. Oxidative stress and beta-cell dysfunction. Pflugers Arch. 2010; 460(4):703-18.

[71] Cuerda C, Luengo LM,Valero MA, Vidal A, Burgos R, Calvo FL, Martínez C. [Antioxidants and diabetes mellitus: review of the evidence]. [Article in Spanish] Nutr Hosp. 2011; 26(1):68-78.

[72] Knowler WC, Barrett-Connor E, Fowler SE, Hamman RF, Lachin JM, Walker EA, Nathan DM; Diabetes Prevention Program Research Group. Reduction in the incidence of type 2 diabetes with lifestyle intervention or metformin. N Engl J Med. 2002; 7; 346(6):393-403.
[73] Lindström J, Louheranta A, Mannelin M, Rastas M, Salminen V, Eriksson J, Uusitupa M, Tuomilehto J; Finnish Diabetes Prevention Study Group. The Finnish Diabetes Prevention Study (DPS): Lifestyle intervention and 3-year results on diet and physical activity. Diabetes Care. 2003; 26(12):3230-6.

[74] Sharma AM, Is there a rationale for angiotensin blockade in the management of obesity hypertension? Hypertension. 2004; 44(1):12-9.

[75] Wheeler DC, Chana RS. Interactions between lipoproteins, glomerular cells and matrix. Miner Electrolyte Metab. 1993; 19(3):149-64.

[76] Oda H, Keane WF.Recent advances in statins and the kidney. Kidney Int Suppl. 1999; 71:S2-5.

[77] Scott CL. Diagnosis, prevention, and intervention for the metabolic syndrome.Am J Cardiol. 2003; 92(1A):35i-42i. 